Portland State University

PDXScholar

\title{
The Queer Innocence of James Baldwin in Giovanni's Room
}

Grace C. Carroll

Portland State University

Follow this and additional works at: https://pdxscholar.library.pdx.edu/honorstheses

Part of the English Language and Literature Commons Let us know how access to this document benefits you.

\section{Recommended Citation}

Carroll, Grace C., "The Queer Innocence of James Baldwin in Giovanni's Room" (2017). University Honors Theses. Paper 511.

https://doi.org/10.15760/honors.516

This Thesis is brought to you for free and open access. It has been accepted for inclusion in University Honors Theses by an authorized administrator of PDXScholar. Please contact us if we can make this document more accessible: pdxscholar@pdx.edu. 
The Queer Innocence of James Baldwin in Giovanni's Room

\author{
by \\ Grace Carroll
}
An undergraduate honors thesis submitted in partial fulfillment of the requirements for the degree of
Bachelor of Arts
in
University Honors
and
English

Thesis Adviser

Dr. Sarah Ensor

Portland State University

2017 


\section{The Queer Innocence of James Baldwin in Giovanni’s Room}

Near the beginning of James Baldwin's 1956 novel Giovanni's Room, the narrator, David, recalls a conversation he had about his lover, Giovanni, after he was sentenced to execution. In it, David's friend Jacques remarks upon the garden of Eden and its temporary nature. The narrative breaks focus from the past to allow for this moment of David's introspection, in the present. During this passage, David says:

Nobody stays in the garden of Eden. Jacques' garden was not the same as Giovanni's, of course. Jacques' garden was involved with football players and Giovanni’s was involved with maidens ... Perhaps everyone has a garden of Eden, I don't know ... Perhaps life only offers the choice of remembering the garden and forgetting it ... People who remember court madness through pain, the pain of the perpetually recurring death of their innocence (Baldwin, 25).

This passage emerged as a site of interest for me due to the way it frames loss of innocence--and, therefore, innocence itself--as "perpetually recurring." Baldwin suggests here an innocence made queer by this recursive quality. Queer innocence is not something which is simply lost; it can be found again. This notion challenges the idea of innocence in literature that we are familiar with. Going back to the story of Adam and Eve (referenced by David in this passage), we see innocence lost as a result not only of sin, but also of acquiring knowledge. Milton reiterates the same story in Paradise Lost. Similarly, a loss of innocence via sexuality is 
required by the "coming of age" narrative or the "marriage plot," which follow a character from childhood to adulthood. From Telemachus to The Catcher in the Rye, loss of innocence has come to signify a transformative experience which indelibly changes a character's perspective. Even at the time of Baldwin's writing, "loss of innocence" is recognizable as a main trope in many novels, present in works which now define classic 20th century literature. Despite their differences, these texts all frame innocence as something whose loss is compulsory.

Giovanni's Room departs quite dramatically from this stance. Baldwin's representation of loss of innocence (and therefore, of innocence itself) as "perpetually recurring" complicates a dominant idea in literature, that of innocence lost and not to be found again. This novel also presents itself as an interesting site through which to explore this theme, due to its subject matter. One might feel compelled to wonder where there is room for innocence in a novel about love and desire between adult men, especially when one of these men is later tried for murder. The dissonance here is as integral to Baldwin's engagement with innocence as its recursivity. Innocence in Giovanni's Room is non-normative due to its intersection with (and, indeed, dependence on) questions of desire, knowledge, shame and guilt. It is by working with these topics, which are typically seen as oppositional to my subject, that I investigate the queer innocence that Baldwin depicts in this text.

The question presented by queer innocence, as defined by its "perpetually recurring death," is in the seeming impossibility of repetition in something predicated on prematurity, and located in the past. If innocence is voided by knowledge, how is it possible to experience it over and again, even with loss as the unavoidable outcome? This pattern of repetition--implied by the words "perpetually recurring"--is accentuated by the narrative structure Baldwin chooses for the novel. This is to say that both innocence and time in the novel function in non-normative ways. 
Giovanni's Room lacks the typical loss of innocence character arc, instead providing a somewhat scattered narrative through which we are immersed in the memories of our narrator, David. From the first page, Baldwin uses the present tense voice to throw the reader directly into the thoughts of his narrator. David is quick to set the tone, announcing that he is awaiting the "most terrible morning of [his] life" (Baldwin, 1), and only a few pages later we learn that this is because a man named Giovanni is "about to perish, sometime between this night and this morning, on the guillotine" (Baldwin, 5). It is with this present tense narrative voice that the novel begins and concludes, and this voice which gives us access to the past, to the events which make up the majority of the novel's plot. The importance of this is emphasized by David, standing before a window in the south of France. Here, there is a strong element--both literal, and figurative--of reflection. There is the "darkening gleam of the window pane" (Baldwin, 1) through which David watches his image in the glass, and the self-examination encouraged by this action.

In Giovanni's Room, Baldwin rejects linear plot development. This is evident from the first few pages, as the reader learns of what might typically be the climax (Giovanni's execution), before we have even been introduced to this character, from whom the novel gets its title. As far as the present tense is concerned, its timeline is outlined here. It is confined to this late night of reflection, as David recalls the recent months he spent in Paris. The reader soon finds out that this time was originally meant to be spent waiting for Hella to return from Spain, where she was pondering the marriage proposal David made prior to her departure. However, by the time the reader learns this, they also must know that something has gone awry. "People are too various to be treated so lightly," David says, "I am too various to be trusted. If this were not so, I would not be alone in this house tonight" (Baldwin, 5). In this way, the temporal structure of the narrative reveals that the content of this novel is not so concerned with what has happened, 
but with this act of self-reflection which David has been motivated to engage in as a consequence of these events. Though at a structural level, the novel's exploration of David's memories allows some more-or-less linear development of plot, the strange qualities of Baldwin's portrayal of time--through his use of multiple tenses--primes the reader to see time as a site of trouble.

The non-normative temporal organization of the novel allows for great movement through time. The reader is able to follow David's memories through his childhood and adolescence, up to his recent months in Paris, all the while retaining a persistent present tense voice to ground us. It is this voice which reveals itself, then, as a useful intermediary between these different points in the past. This is a consistent pattern throughout the novel, and it is in this way that the reader comes to track "the flight which has brought [David] to this darkening window" (Baldwin, 10). I would like to suggest that it is this, too, which allows us to explore the "perpetually recurring death of innocence" in Giovanni's Room. As David forms a narrative based off of the cyclical exchange between past and present, we are able to track episodes of innocence lost and found throughout the novel.

The normative configuration of innocence leaves it as something which is, in some cases, undone by desire. Because of this, the relationship between innocence and desire is one which is based on loss. Meaning, that it is through mourning lost innocence that innocence and desire typically are allowed to be situated adjacent to one another. By this model, these two concepts are not fully united, as their relationship is established as a function of (supposedly uncrossable) distance, and lamentation. In this, desire can still be seen as removed from innocence, and vice versa, desire for innocence emerges only from its loss. However, Giovanni's Room creates a space in which innocence and desire actually share the same space. 
It is in reference to Hella, David's fiance, that we first see this uncanny alignment of innocence and desire, as he considers the conditions which motivated his marriage proposal. "I told her that I had loved her once and I made myself believe it," he says. "But I wonder if I had. I was thinking, no doubt, of our nights in bed, of the peculiar innocence and confidence ... which had made these nights so delightful" (Baldwin, 35). Whereas it is so typically an initiation into sexuality which signals loss of innocence throughout books and other media, here David seems to retain some state of innocence through this interaction with Hella. This becomes more puzzling still when we take into account the initial loss of innocence David portrays.

David's first foray into the past tense is on the theme of desire, as he confesses his sexual history with men. "I repent now--for all the good it does--one particular lie among the many lies I've told, told, lived, and believed ... that I had never slept with a boy before" (Baldwin, 6). This is how we are introduced to Joey, a high school friend of David's and the first boy who he had sex with. In this scene, the desire which facilitates David's loss of innocence becomes inextricably linked to queerness. Because of the way that desire becomes a main problem of this narrative, I consider it of some importance to understand the affective qualities of desire in the text.

As David recalls what it was like to spend time with Joey, he creates a rare mood of happiness, of feeling carefree. "I was proud, I think, because his head came just below my ear. We were walking along ... and we were laughing. Odd to remember ... how good I felt that night, how fond of Joey" (Baldwin, 7). He adds to this pleasant tone a collage of conflicting sensory details. There are the "dark, tropical Brooklyn streets with heat coming up from the pavements ... with enough force to kill a man," along with the sting of weaponized wet towels and, perhaps, of a bedbug bite (Baldwin, 6-7). It is in examination of that last discomfort which 
led to the "touch different from any touch either of us had ever known" (Baldwin, 8). This touch is accompanied by the "awful" beating of David's heart, the too-bright lights and oppressive heat of the room (Baldwin, 8). However, this episode concludes on a jubilant note. "Out of this astounding, intolerable pain came joy; we gave each other joy that night" (Baldwin, 8). In this way we see desire as something which contains both pain and pleasure.

Not only does this scene depict a first sexual encounter, but it is one which is apparently worthy of "repentance." In introducing this theme of desire, Baldwin also establishes a tone which will dominate the present tense voice, and that is the tone of the confessional. In this way, it is through David's desire that the reader also comes to know his guilt. However, antithetical as guilt is to innocence, I am unable to simply equate the desire which produced these negative affects with loss of innocence.

In "Queer Optimism," Michael Snediker tries out a theme which, in the conversation about queer theory and affect, is often ignored. The optimism which Snediker critiques is "often imagined epithetically as 'premature' ... [which] would qualify optimism as a temporary state of insufficient information" (Snediker, 1). Snediker's thoughts on optimism became interesting to me due to the similarities I was able to draw between this description and the function of innocence. Due to its connotations with naivete, with childhood, there is a deficit of information which typically is required of innocence. We see this in literary configurations of loss of innocence, as it is also knowledge, or some heightening of perception, which marks the pinnacle of the coming-of-age story. And it should be kept in mind that Eve's departure from naivety was not only in committing "original sin" but in the knowledge of sin which was produced by this initial act. Innocence cedes to the acquisition of knowledge. In the encounter between Joey and 
David, there is the unconscious gap between innocence and guilt, that time during which sleep delays the knowledge which would complete this fateful transition.

Despite the beauty and joy which made it seem "that a lifetime would not be long enough ... to act with Joey the act of love," it is soon made clear that that separate "lifetime" was "bounded by that night" (Baldwin, 8). Once David wakes up the morning after he looks upon Joey, still asleep, and is met by the a rush of information which comes from self-scrutiny. "My own body suddenly seemed gross and crushing and the desire which was rising in me seemed monstrous ... It was borne in on me: But Joey is a boy" (Baldwin, 9). Though Joey's maleness can hardly be considered new information, David's own relationship to that maleness has changed. It is this realization which turns Joey's body into a living death sentence for David, whose innocence--and pride--is so tied to his "immaculate manhood" (Baldwin, 30). He says, "that body suddenly seemed the black opening of a cavern in which I would be tortured till madness came, in which I would lose my manhood. Precisely, I wanted to know that mystery and feel that power and have that promise fulfilled through me" (Baldwin, 9). Though it is an experience of desire which leads him to this action, it is the knowledge gained through this episode of self-reflection which gives way to panic, and to shame.

As confirmed by David's terrifying realization of Joey's maleness, this sense of shame is directly related to a perceived entrance into queerness. "I was afraid. I could have cried ... for shame and terror ... for not understanding how this could have happened to me, how this could have happened in me" (Baldwin, 9). David frames his homosexual experience as a threat both external and internal, and one which has enacted a shift in his experience of selfhood. It is through this that my questions about recursive innocence are met by the curious structure of the narrative. As he said, after the passage about Joey, "that lifetime was short and bounded by that 
night" (Baldwin, 8). The language in this passage suggests, in a quite literal fashion, the pattern which comes to characterize David's narrative, this action of splitting. To specify "that lifetime," would imply multiple lifetimes, similar to the multiple states of innocence required by a "perpetually recurring death."

In "Imitation and Gender Insubordination," Judith Butler speaks of identity as something which is based on and created through a structure of repetition. "The 'I' only achieves the semblance of identity through a certain repetition of itself' (Butler, 125). By acknowledging his desire, David calls to light a breach in the performance of his own identity, and in the naming of this experience as queer there is not only a loss of innocence but a disruption of identity. Considering queerness as an identity means that David has to reinvent himself, in a way, to escape its threat. This poses a problem for our narrator, one which disrupts the procession of his story and comes to shape the structure of his narrative.

David's desire for innocence is apparent in his lamentation on the garden of Eden, and in the aversion to shame which becomes a primary motive for our narrator. Indeed, the function of desire in Giovanni's Room is perhaps all the more queer due to the way in which it functions outside of the context of sex. As Jacques may desire "football players" and Giovanni may desire "maidens," David desires that which is normally undone by desire itself. Through a rejection of knowledge, David is able to pursue innocence and, paradoxically, to approach this state again. Simultaneously, though, David's own figuring of innocence situates it in the same space as desire. Deconstructed through a lens of sexuality, desire is separate from the act which it inspires, though it is, in some ways, dependent on the potential of acting. From David's situation of innocence within this text, it would appear that it holds some relation to the pain and pleasure before consummation, the purity of desire before the knowledge which informs shame. We see 
this in David's experience with Joey, through his engagement with the garden of Eden, and as we will see this through his reflection at the end of the novel, in thinking about Giovanni's room. The queerness of this innocence is exacerbated by its relationship with desire, one which encourages the temporal (dis)organization of the narrative, as David must resort to self-deception in order to expunge the knowledge which corrupted his sense of innocence.

As David goes on to abandon Joey, he starts a long process of abandoning himself. Or, rather, of multiplying himself in some attempt of dissociation or self-renunciation. In this case, the shame born of his desire for Joey coaxes David into a state of denial where it is not just the act which is prohibited, but the agent. To continue with this, David must contrive of, in some senses, a new life. Joey is replaced by a "rougher, older crowd" and a fictional girlfriend (Baldwin, 10). It is in his rejection of Joey that David rejects the knowledge which causes him to lose his innocence, that of his "shameful" desire. His recollection of his "days in bed" with Hella, of the uncanny "innocence and confidence" which belonged to that time, would suggest that there is some success in this self-deception. There is, in any case, an implicit reclamation of innocence.

It is perhaps in this same state of innocence that David first goes to Guillaume's bar. Despite his prior experience with Joey, David identifies himself as "queer for girls" (Baldwin, 30). There is a sense of latent discovery present in this scene, one which is connected to David's navigation of sexuality. When David arrives, he feels as though he is under the surveillance of the other men there. "It was as though they were the elders of some strange and austere holy order and were watching me in order to discover, by means of signs I made but which only they could read, whether or not I had a true vocation" (Baldwin, 27). David identifies as heterosexual, and his entry into a queer space is represented here as an initiation, of sorts. Here, sexuality is 
framed as a discovery. To code this scene as an experience which David approaches innocence is to negate his prior experience, demonstrating the aversion to knowledge (as it involves the self) which facilitates the fracturing not just of the narrative, but of David as our narrator.

When David first meets Giovanni, we see a time of new beginnings, filled with hesitancy. “'Don't you know when you have made a friend?' [Giovanni] said, 'what is this thing about time? ... People are always saying, we must wait, we must wait. What are they waiting for?"” (Baldwin, 37). David's painful self-consciousness, being the center of attention, frames his meeting Giovanni as an event which would would require spectators. "I watched [Giovanni] as he moved. And then I watched their faces, watching him. And then I was afraid. I knew that they were watching, had been watching both of us. They knew that they had witnessed a beginning and now they would not cease to watch until they saw the end" (Baldwin, 38). It is through this that their relationship is marked as having a transformative quality.

When David first goes to Giovanni's room, we see the split affective qualities of desire again. "For a moment, in the gloom, we simply started at each other--with dismay, with relief ... With everything in me screaming No! yet the sum of me sighed Yes" (Baldwin, 64). It would seem as though through Giovanni, David has lost his innocence yet again, through giving in to that which causes him shame. Looking back to the novel's beginning, seemed that Giovanni was the "awful, irrevocable thing" which happened to David, which would suck out all the joy from his relationships to come. As he said, "Now, from this night, this coming morning, no matter how many beds I find myself in between now and my final bed, I shall never be able to have any more of those boyish, zestful affairs" (Baldwin, 5). However, the novel's final pages show that this, too, is subject to the unreliability of David as our narrator. 
The structure of the novel renders Giovanni's initial question a good one. "What is this thing about time?"' (Baldwin, 37). Even in the sense of the future as near at hand, as the coming morning which will be the "most terrible" of David's life (Baldwin, 1), the time to come is only promissory in the sense that it is dooming. From even this vantage point in the novel, the future (whether near, as it is here, or far) lacks the sense of movement it is usually guaranteed. One of the most anticipatory passages of the novel occurs at its very beginning, as David contemplates his return to Paris. "The train will be the same, the people, struggling for comfort and, even, dignity on the straight-backed, wooden, third-class seats will be the same, and I will be the same." (Baldwin, 1). The sense of possibility which is often held by the future is missing here-due to the concreteness of the future tense, as compared to something more conditional. The absence of this excitement is soon concretized by the "cavern" to which David condemns himself, as a consequence of the shame. In this way, we can see that the shame which results from queerness as something which forecloses upon the future.

It is strange, though, that in a book which makes such great movements through space and time, one which employs a narrator who is "in a state of constant motion" (Baldwin, 20), there is a pervasive feeling of "stuckness." Through all the different shifts in perspective, corresponding to different parts of David's life, we are always returned to the present tense. However, upon closer examination, this use of the present tense seems completely unnecessary, as the events which make up the plot of the novel occur entirely in the past. It is through the persistent present tense that we are allowed to see, in a sort of revisionist history, events of the past in the light of the present. One example of this is when David is recalling his later days with Giovanni, when they "dawdled as doomed mountain climbers ... above the chasm" (Baldwin, 114). Giovanni takes up an interest in remodeling the room, chipping a bookshelf into the bricks. 
In a moment of present tense introspection, David breaks his retrospection to say, "Now--now, of course, I see something very beautiful in those days, which were such torture then" (Baldwin, 114). Here, the "torture" of the past becomes the "beauty" of the present.

Indeed there is a confessional tone to David's voice, reinforcing the presence of shame in the narrative, but there is also a testimonial quality in this extraneous present tense voice. This is apparent in the shifts David makes in narrating different episodes of his life, in the way that he must interject in the present tense to say "I remember" rather than allowing a distance in time to be communicated solely through the use of the past tense. This effect of this is to make prominent the feeling of guilt. This leads me to understand David's use of the present tense as facilitating a sort of cross-examination of the self (via his reflection), this would frame David's narrative as a type of witness statement. It is the present tense voice, too, which informs the reader that all of this reflection on David's part, is occurring as Giovanni is due to be executed. So as his lover begins to serve his sentence, David is in some being prosecuted through a trial of his own making.

The final pages of the novel return the reader again to the present tense, to David as he stands alone in his rented room. "There is a mirror in this room, a large mirror. I am terribly aware of the mirror" (Baldwin, 167). There is a symmetry in the novel's use of the present tense. It bookends the novel's opening and its end, and in these passages are heavy with the implication of reflection, as though to explain everything that the reader has just witnessed or everything that they are about to witness, through David's narration. "The body in the mirror forces me to turn and face it. And I look at my body, which is under sentence of death ... And I do not know what moves in this body, what this body is searching. It is trapped in my mirror as it is trapped in time and it hurries toward revelation." The agency which David has denied himself throughout this 
novel--through denial, self-deception, but also through the helplessness with which he describes his movements and behavior--seems to have left us with a narrator fully dissociated from his physical form. And for a moment it is as though David's fracturing of self has finally gone too far to be reconciled.

As the novel itself comes to an end, David's own confessional is wrapping up. However, it is with a sickening sense of repetition that this occurs, through an invocation of Corinthians, 13:11. "When I was a child, I spake as a child, I understood as a child, I thought as a child: but when I became a man, I put away childish things" (Baldwin, 168). Here we see this co-opted loss of innocence character arc complete itself, as David purportedly resolves to "grow up." David's use of Corinthians seems to speak to moving on, forgetting about Giovanni. The end of the novel shows the fracturing of David, if not as a narrator, then as a character. It shows up through the "putting away of childish things" and the attempted severance of his connection to Giovanni, to a part of his past. I find it interesting that "moving on," in this case, is identified as the putting away of "childish things." This identifies David's severance from Giovanni as a loss of innocence.

This is interesting, because throughout the novel, it would seem as though it was through losing Giovanni that David also lost his innocence. David's initial depiction of meeting Giovanni, though, used the same coding to depict loss of innocence. In this way, the end of the novel presents a considerable contradiction, as the closing passage suggests that David existed within a state of innocence while with Giovanni. As the Corinthians quote indicates a movement towards the manhood which David so prizes, David makes some attempt to wrestle his way back into innocence. The decisiveness which comes through in his citation of Corinthians results in action. He tears up the letter containing the date and time of Giovanni's execution. "I take the 
blue envelope which Jacques has sent me and tear it slowly into many pieces, watching them dance in the wind, watching the wind carry them away. Yet, as I turn and begin walking toward the waiting people, the wind blows some of them back on me" (Baldwin, 169).

However, at the end of this mock trial, this prosecution of the self, David seems to have come to a contradictory verdict. This is not a bildungsroman, a story of learning. In fact, the affective tenor of the present, that element of suspension, would argue for the opposite. It helps me think about this in terms of movement. David describes himself as "in constant motion" yet what we are left with is the "dawdling," the "stillness," the stasis. Innocence is similar to optimism, as described by Snediker, in that it expects termination by the future. But what happens when one does not have access to the future?

In other texts, innocence is something which comes with childhood and is lost along the way, at the advent of sex or some perspective-shattering experience. However, in Giovanni's Room this process is disrupted by its own repetitions. Surely, David loses a kind of innocence as he sleeps with Joey. But his own account suggests that this is regained in time for him to sleep with Hella, and is retained long enough for him to lose it again with Giovanni. However, even this seems, by the novel's end, to be reframed as some kind of innocence, when David recognizes the "beauty" in what seemed like "torture."

In this we see innocence for what it is, a lens which is part of how a person navigates the world. There is a queerness in the way this works, though. Snediker says that "the moment at which a person is able to characterize her optimism ... might well mark the moment at which being optimistic cedes, as a position" (Snediker, 1). Innocence works very much in the same way, and perhaps it is for this reason that we see David gazing upon his own image in that darkened window. In this act, David is effectively othering himself, making himself the unknown 
and unknowable figure which can be an object of his own observation. I would then like to apply Snediker's thoughts on the cessation of optimism to David's experience of loss of innocence. If innocence is something with this "allergic relation to knowledge" (Snediker, 1), then it is something which you can only see once it has passed, when it is behind you. Innocence is elusive because it cannot be found by looking straight forward. David's focus on his reflection, the act which he participates in as well as the image of himself which aids this act, requires something like a rearview mirror.

Queer innocence seeks to complicate how innocence is manifest, here through the text of Giovanni's Room. In this way, it challenges dominant depiction of innocence as singular, connected to childhood, and located in the past. As Baldwin clears room for this exploration by imbuing innocence with the potential to be "perpetually recurring" (even in its own death), this implicitly involves ideas which have previously been seen as oppositional to innocence, such as knowledge. Even a more concrete text, one shaped by a narrator who is perhaps not "too various to be trusted" (Baldwin, 5), would not inspire me to pursue a definition of queer innocence. Rather, my hopes for working with this text were to think about what does queer innocence do? In Giovanni's Room, it seems that it is this queer innocence which is able to shape not just a narrator, but an entire narrative, at a structural level. The argument of my thesis, then, is for the usefulness of a queer reading of innocence and the potentials for understanding that this may enable. What if innocence could be more than something to be mourned, but something to be interested in? What if it can be understood--and itself become a site of understanding--through the very things which it is presumed to forbid? The power of queering innocence is in the ability to speak of innocence when it does not look like innocence anymore. For David, even with all the haunting effects of loss, it ultimately shows us the power of innocence to change the affective 
qualities of the past. After a literary history plagued by innocence lost and not to be found, this may very well be liberating in itself.

\section{Bibliography}

Baldwin, James. Giovanni's Room. New York: Dial Press, 1956. Print.

Berlant, Lauren. Cruel Optimism. Duke University Press, 2011.

Butler, Judith. Imitation and gender insubordination. Routledge, 1991. 
Edelman, Lee. No future: queer theory and the death drive. Duke University Press, 2007.

Muñoz, José Esteban. Cruising utopia: the then and there of queer futurity. New York University Press, 2009.

Snediker, M. "Queer Optimism." Postmodern Culture, vol. 16 no. 3, 2006. Project MUSE, doi:10.1353/pmc.2006.0030 